\title{
Molecular Screening of Staphylococcal Enterotoxin Type P Encoding Gene From Clinical Isolates
}

\author{
Ramezan Ali Ataee ${ }^{1}$, Mojtaba Hedaiatich ${ }^{2}$, Rahim Mansuor Khanshan ${ }^{2}$, Mohammad Hosein \\ Ataee $^{2, *}$ \\ ${ }_{1}^{1}$ Department of Medical Microbiology, Faculty of Medicine, Baqiyatallah University of Medical Sciences, Tehran, IR Iran \\ 2 Applied Microbial Research Center, Baqiyatallah University of Medical Sciences, Tehran, IR Iran \\ ${ }^{*}$ Corresponding author: Mohammad Hosein Ataee, Applied Microbial Research Center, Baqiyatallah University of Medical Sciences, Tehran, IR Iran. Tel: +98-2188067969, Fax: +98- \\ 2188039883, E-mail:ataee216@gmail.com.
}

Received: May 15, 2012; Revised: July 29, 2012; Accepted: Aug 8, 2012

\begin{abstract}
Background: In recent years, the roles of Staphylococcal enterotoxins in the non-gastrointestinal diseases have been reported. The most frequently mentioned was enterotoxin type A. But in many cases there are also high similarity with type P. Accordingly, the differentiation of producing enterotoxin type $P$ strains from type $A$ is essential.

Objectives: The objective of this study was to assess and characterize Staphylococcus aureus containing entP gene from infectious specimens.

Materials and Methods: Based on the reference sequence (S. aureus N315 entP gene), pair primers were designed. 350 clinical strains of $S$. aureus were assessed by polymerase chain reaction(PCR). The purified PCR product was sequenced. All isolated S. aureus strains containing the entP gene were tested by Enzyme immunoassay.

Results: The PCR amplification method was optimized for entP gene detection. The used primer pairs were amplified for $213 \mathrm{bp}$ and 700 bp fragment separately. The sequencing results indicate that only 98 (28\%) out of the 350 strains of S. aureus contained entP gene. The results of Enzyme immunoassay test for enterotoxins detection revealed that $79(22.57 \%)$ of the strains contained entP gene were which also produced other enterotoxins (such as enterotoxin A to E) and 19 (5.43\%) of the strains were carriers of only enterotoxin P gene unable to produce other enterotoxins.

Conclusions: The results revealed, the specific primers that amplified the entE gene were able to amplify the Staphylococcal EnterotoxinLike Toxin Type P gene. The specific primers for the entP gene were amplified a fragmented gene (700 bp) showed 100\% homology with entP reference gene and also 80\% homology with entA and entE genes.
\end{abstract}

Keywords: Staphylococcus aureus; Enterotoxins; Polymerase Chain Reaction

\section{Background}

The most virulent factors of Staphylococcus aureus are enterotoxins (SEs) that cause food poisoning and toxic shock syndrome $(1,2)$. SEs are potent inducers of cytotoxic T-cell activity and cytokine production in vivo (3). In addition, SEs are being increasingly recognized for their possible roles in many other human diseases, such as atopic dermatitis (4), Kawasaki syndrome (5), nasal polyposis (6) and certain autoimmune disorders (7). Accordingly, to clarify the role of the causative agents of human diseases caused by staphylococcal enterotoxins, it is necessary to have further assays for them (8). However, in terms of frequency and/or seriousness of disease some kind of bacterial toxins play a more important role.

S. aureus is a facultative aerobic Gram positive cocci, colonizes up to $50 \%$ of humans (9) and may release enterotoxins. The organism most often colonizes the anterior Nose and may also colonize other parts of body surfaces, including mucous membranes and damaged skin. Staphylococcal enterotoxin serotypes A-E (SEA-SEE) and SEG-SEQ have been widely studied $(10,11)$. SEA-SEE and SEI are found to be capable of causing vomiting and diarrhea when administered to animals likes monkeys (12). The rest of enterotoxins (SEG, K, L and Q) as superantigens may also have emetic activity or have not been tested for this mode of action (13). Based on current research,

Implication for health policy/practice/research/medical education:

Patients undergoing percutaneous coronary intervention (PCI) are amongst the individuals with highest risk for developing adverse cardiac events and higher morbidity and mortality. There are different reports in various studies about the rates of dyslipidemia control. Present study concluded that lipidlowering agents and regular follow-up visits did assist in achieving lipid-control goals in our patients, but a large proportion of the patients remained dyslipidemic at the end of the follow-up period. More attention should, therefore, be paid to life style modification, using statins with higher doses, and utilizing other classes of lipid-lowering agents such as ezetimibe or fibrates, if needed, in order to achieve the optimal targets of LDL-C, HDL-C, and TG.

Copyright (c) 2013, Ahvaz Jundishapur University of Medical Sciences; Licensee Kowsar Ltd. This is an Open Access article distributed under the terms of the Creative Commons Attribution License (http://creativecommons.org/licenses/by/3.0), which permits unrestricted use, distribution, and reproduction in any medium, provided the original work is properly cited. 
the staphylococcal enterotoxin A (SEA) is the most commonly reported in clinical isolates, especially from food poisoning $(11,14)$, and it is an extremely potent gastrointestinal toxin; as little as $100 \mathrm{ng}$ of this toxin is sufficient to cause symptoms of intoxication (1). However, the role of this toxin in organs other than gastrointestinal tract remains unclear.

There are several reports that investigated the biological properties of a novel staphylococcal enterotoxinlike toxin type P (SEIP) $(8,15)$. SElP induces a substantial proliferative response and the production of cytokines interleukin-2, gamma interferon, tumor necrosis factor alpha and interleukin- 4 from human T cells when administered at a concentration of $0.4 \mathrm{pm}(0.01 \mathrm{ng} / \mathrm{ml})$ or more and in mice implanted with an osmotic pump filled with SE-like type P showed 78.1\% homologous with staphylococcal enterotoxin type $A(16)$. The results of some reports has showed that the coagulase-negative staphylococci (CNS), isolated from animal and human cases are carrier of genes encoding enterotoxins and enterotoxin-like toxins protein $(17,18)$.

\section{Objectives}

The aim of this study was to isolate and characterize the S. aureus producer of enterotoxin P and related enterotoxins like proteins from infectious specimens.

\section{Materials and Methods}

\subsection{Criteria for Selection of Bacterial Strains}

All patients were examined by a specialist in the infectious disease department and they were then referred to the molecular bacteriological laboratory. The Gram stain, catalase, coagulase, DNase, ability to grow on mannitol salt agar (Lot 105404752 Merck Germany) were enrolled in this study. The 350 strains of S. aureus were isolated from superficial infected tissue; blood, synovial fluid, feces, throat, urine and spinal fluid. The collected isolated strains were maintained at $-20^{\circ} \mathrm{C}$ within $20 \%$ glycerol.

\subsection{Bacteria Culture and DNA Extraction}

Bacterial genomic material was extracted with modified salting out methods (19). To summerize, each single-colony of bacteria was inoculated into LB broth (Lot VM1322685, Merck Germany) medium separately. After 24 hours incubation, $1 \mathrm{ml}$ of content was transferred into a $2 \mathrm{ml}$ sterile micro tube and centrifuged (10 $\mathrm{min}$ in $5000 \times \mathrm{g}$ at $\left.4^{\circ} \mathrm{C}\right)$. The supernatant was discarded, and then $400 \mu$ l STE buffer (Tris-HCl 10mM, NaCl 10 mM, EDTA $1 \mathrm{mM}, \mathrm{pH}=7.5$ ) was added to re-suspend the cell-sediment completely. In addition, $125 \mu$ of $2 \%$ sodium dodecyl sulfate (SDS) and $250 \mu \mathrm{l}$ of $3 \mathrm{M}$ sodium acetate was added to the tube and the content mixed by gently inverting for 10 times. Afterwards, the tube was centrifuged ( $5 \mathrm{~min}$ in
$3000 \times \mathrm{g}$ at $4{ }^{\circ} \mathrm{C}$ ) to lead DNA into supernatant. The supernatant was transferred into a new sterile tube. $750 \mu \mathrm{l}$ of cold absolute ethanol was added and it was kept overnight at $-20^{\circ} \mathrm{C}$.

Next day, the tubes were centrifuged $(12000 \times \mathrm{g}$ for $20 \mathrm{~min}$ at $4{ }^{\circ} \mathrm{C}$ ), the supernatant was discarded and the sediments let to dry. Volume of $750 \mu$ l of $70 \%$ ethanol was added to sediments and after 1 hour the product was centrifuged $\left(12000 \times \mathrm{g}\right.$ for $20 \mathrm{~min}$ at $\left.4{ }^{\circ} \mathrm{C}\right)$. The supernatant was discarded again and sediments let to dry completely at room temperature. Then adding $50 \mu \mathrm{l}$ D.W to each tube and incubating them at $37{ }^{\circ} \mathrm{C}$ for $45 \mathrm{~min}$. Applying Nano- Drap (Thermo Scientific NanoDrop 2000 Spectophotometer USA), the concentration of DNA have been measured. $1 \mu \mathrm{l}$ of genomic product solution transferred into new tubes and stored in $-20^{\circ} \mathrm{C}$ to use as template for PCR when needed.

\subsection{Primer Design}

Based on the reference sequence (S. aureus N315 enterotoxin P gene; accession number BA000018.3) the pair primers were designed by AllelID V2 software, analyzed by primer3 software and multiple alignments was carried out by DNASIS MAX Trial version. Then, it was synthesis by Cinnagene Company (Tehran, I.R. of Iran).

\subsection{DNA Amplification and Sequence Analysis}

For DNA amplification, the master mix was made in 200 $\mu \mathrm{l}$ microtubes. By using a $25 \mu \mathrm{l}$ reaction mixture containing the $5 \mathrm{ng} / 1 \mu \mathrm{l}$ DNA template, 2 unit of Taq DNA polymerase, $5 \mu$ l of 10X PCR buffer II containing $2 \mathrm{mM}$ of each dNTPs, $2 \mathrm{mM} \mathrm{MgCl} 2$ (All reagents were from Fermantase, USA), $10 \mu \mathrm{M}$ of the primer pair(synthesized by Cinnagene Co, I.R. IRAN) and double-distilled water to the final volume of $25 \mu \mathrm{l}$. All the amplifications were carried out in a thermal cycler (Bio- Rad, C1000, USA) with initial denaturation at $94{ }^{\circ} \mathrm{C}$ for 5 min followed by 32 cycles of denaturation at $94^{\circ} \mathrm{C}$ for $1 \mathrm{~min}$, primer annealing at $56^{\circ} \mathrm{C}$ for 1 min and extension at $68^{\circ} \mathrm{C}$ for $1 \mathrm{~min}$, followed by a final extension at $68^{\circ} \mathrm{C}$ for $7 \mathrm{~min}$.

The amplified PCR products were electrophoresed in a 1.5\% agarose gel, and then stained with etidium bromide $(0.05 \mathrm{mg} / \mathrm{mL}$; Sigma Aldrich). The gels were photographed under ultra violet light using Gel Documentation (Bio Rad universal hood II, USA). Molecular size markers (100 bp) were included in each agarose gel. The PCR product was purified (AccuPrep PCR Purification kit Cat No .K-3034-1, Lot No. 10031.) and to determine the sequence, it was sent to the Sequencing Laboratory (Hope Generation Medical Foundation, I.R. Iran).

\subsection{PCR Product Cleans up}

In order to remove the none-specific fragments of PCR reaction product, electrophoresis on $1.5 \%$ Low melting agarose gel have been carried out ( $80 \mathrm{~V}$ for $40 \mathrm{~min}$ ). The 
target band region identified and cut out with scalpel. This piece of gel was transfered into $1.5 \mu$ l sterile microtube and the target band was cleaned up according to AccuPrep Gel Purification kit (Bioneer, Korea).

\subsection{ELISA Assay}

All isolated S. aureus strains has been tested by Enzyme immunoassay for the detection of Staphylococcus enterotoxins A, B, C, D and E kit (RIDASCREEN SET A, B, C, D, E: Art. No.: R4101 r-Biopharm). All reagents required for the enzyme immunoassay are contained in the test kit and it was carried out based on test direction. In brief, each $S$. aureus strain was inoculated into $5 \mathrm{ml}$ of the BHI-broth (Lot 1.1385000500 , Merck Germany) separately and they were incubated at $37^{\circ} \mathrm{C}$ for 24 hours. Then, they were centrifuged $(5000 \times \mathrm{g}$ for 5 minutes at $4 \times \mathrm{C})$ and $100 \mu \mathrm{l}$ of each supernatant was subjected to the ELISA test.

\section{Results}

From August 2008 to September 2011 a total 350 strains of $S$. aureus were isolated from clinical samples and were identified by bacteriological methods (Gram stain, Coagulase, Manitol fermentation and DNase tests). The frequency of the derived (entP gene containing/total) were from: blood (18/63 strains), CSF (14/51 strains), synovial fluid (3/11 strains), throat swabs (27/97 strains), wounds (25/87 strains), stool (5/24 strains) and genital tract (6/17 strains). The results of DNA extraction by the salting out method represented relative purity and concentration. The sample analysis by Nano-Drap methods revealed the absorption ratio outline of $260 / 280 \mathrm{~nm}$ which was above 1.8 , representing the desired purity of the extracted DNA. Agarose gel electrophoresis of DNA extracted by this method showed a favorable and sharp band. As shown in Figure 1.

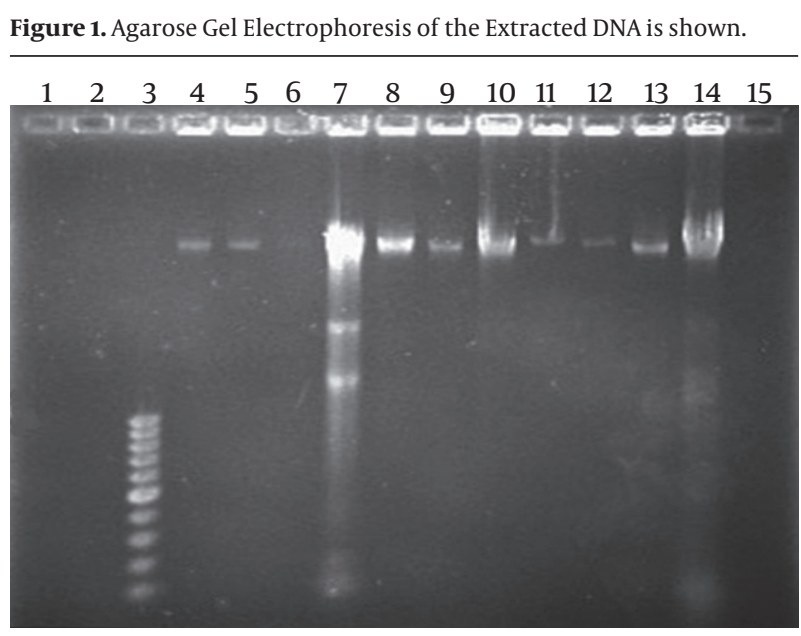

Lanes 1, 2 and 15 are negative controls. Lane 3; is molecular size marker 100 bp. Lanes 4-14 shows the DNA extracted from different staphylococcal Strains

The sequences of the primers pair and their analysis are shown in Table 1. As illustrated in Table 1 the F1 R1 and F2 R2 were amplified a 213 bp (Figure 2, A and B) and 700 bp fragments (Figure 3 ) respectively. In Figure 2, the result of 1.5\% agarose gel electrophoresis of PCR products from primer F1 and R1 are shown.

\begin{tabular}{lllll}
\hline \multicolumn{2}{l}{ Table 1. The Sequences, Lent, Location and Product Size of Primers are Shown } \\
\hline Primers & Sequences & Length & Location & Product Size \\
\hline F1 & 5'-tgt ata tat tgg cgg tgt ctt-3' & $21 \mathrm{bp}$ & 2011809 & $213 \mathrm{bp}$ \\
$\mathbf{R 1}$ & 5'-gct tta agc aat ctt ag-3' $^{\prime}$ & $17 \mathrm{bp}$ & 2012021 & $700 \mathrm{bp}$ \\
F2 & 5'-gtagc GGATCC a gcg aag aaa taa atg gaa t-3' & $31 \mathrm{bp}$ & 2012115 & 2011415 \\
R2 & 5'-gcgcg AAGCTT aaa aat tgc ata tag ata-3' & $29 \mathrm{bp}$ & 2 \\
\hline
\end{tabular}
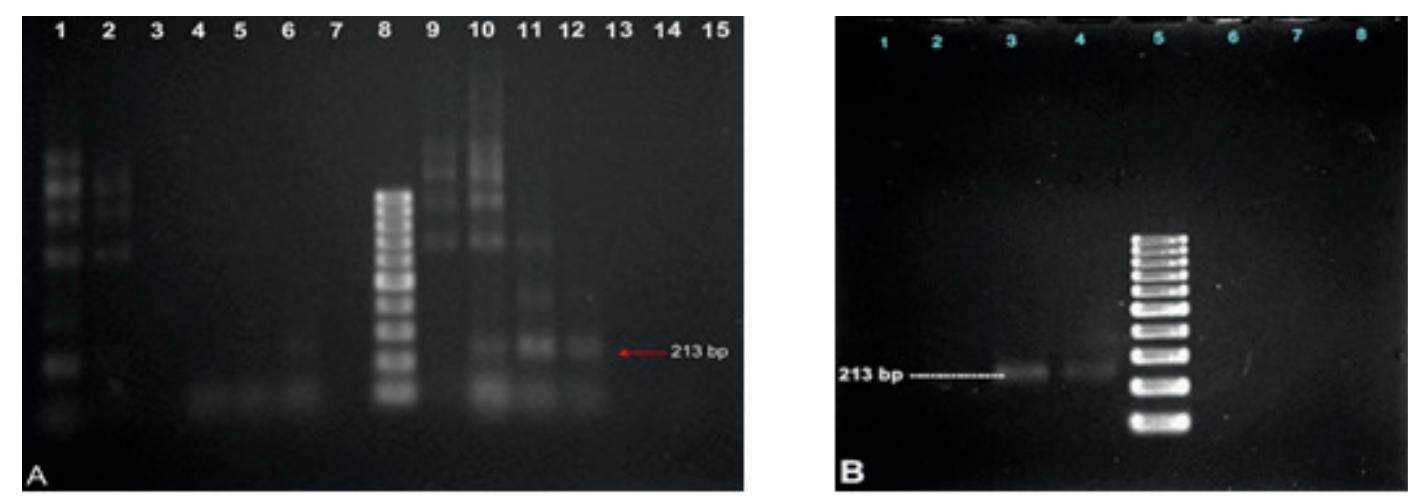

Figure 2. A) Lines 1, 6,10, 11 and 12 are Shown as a 213bp Fragments (partial entP Gene). Line 8 is a 10obp MW Marker. Lines 3, 7, 13-15 are as Negative Control. B). Lines 3 and 4 Showed the Clean up PCR Product 213bp Fragment and Line 5 is 10obp MW Marker 


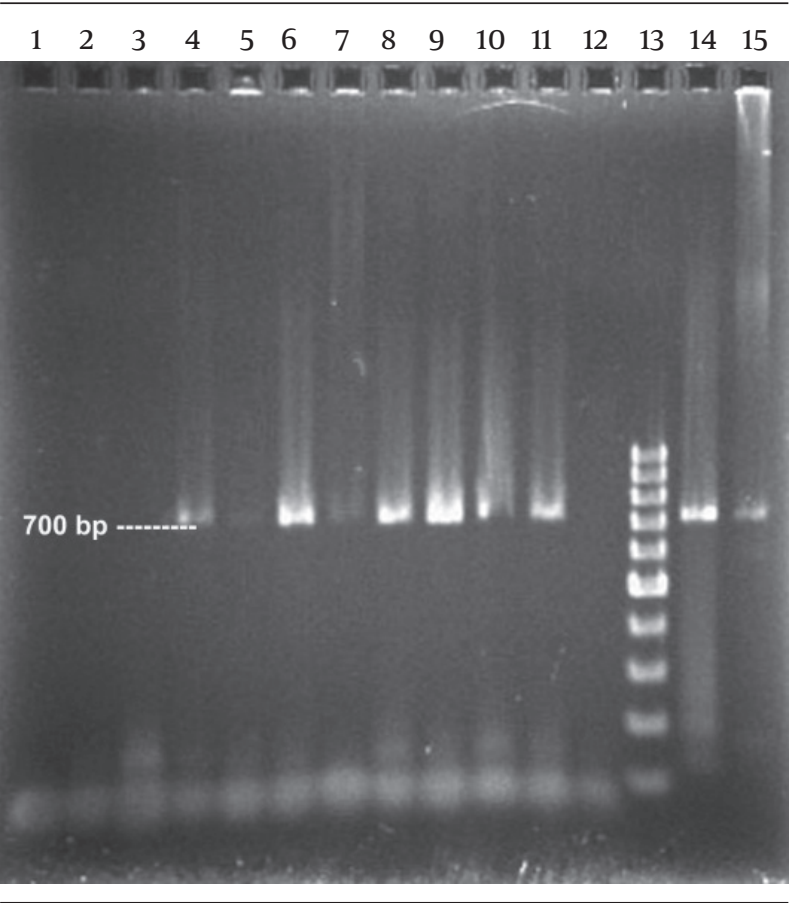

Figure 3. Lines 1, 2, 3 and 12 are as Negative Control. Lines 4-11 and 14-15 Were Shown a 700bp Fragments (Complete entP Gene). Line 13 is a 100bp MW Marker

The results indicate that the PCR method was optimized for entP gene detection. All the 350 isolated strains were studied. The first primer pairs were amplified for $213 \mathrm{bp}$ fragment as well as the second primer pairs which were amplified for $700 \mathrm{bp}$ fragment. The latest fragment were only detected in $98(28 \%)$ out of the 350 strains of S.aureus entP gene. The distribution of $98 \mathrm{~S}$. aureus strains which carries entP gene were isolated from blood (18 strains), CSF (14 strains), Synovial fluid (3 strains), throat swabs (27 strains), wounds (25 strains) and stool (5 strains) and genital tract (6 strains).

The DNA sequencing of amplicon 700bp fragment of staphylococcal enterotoxin P gene as PCR product was carried out by the Iranian company sequencer (Hope Generation Medical Foundation, I.R. IRAN). The result of multiple alignment of the reference gene (S. aureus strain N315 enterotoxin P gene, accession number BA000018.3) with the outcome sequenced PCR product obtained in this study is shown in figure 4 . In order to prevent contamination, each of the samples was analyzed separately. In this study, there was not specific antibody against staphylococcal enterotoxin P. Thus available, the culture supernatant of all strains containing enterotoxin P genes was subjected to ELISA test. The noteworthy finding was that, some strains containing entP gene were also carrying other Enterotoxin genes.
Figure 4. The 700 bp Fragment Amplified (Purified PCR Product) in This Study Was Sequenced and Alignment with Reference Enterotoxin P Gene (accession number BA000018.3) Was Shown.

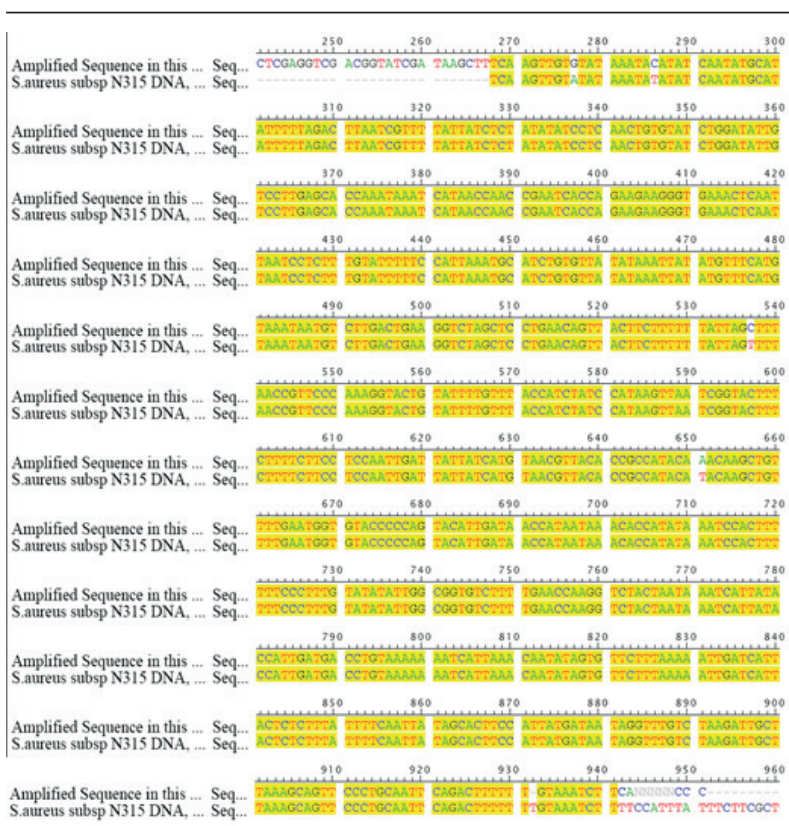

The First Row Sequence is related to PCR Product Derived From This Research and the Second Row is Reference Gene.

\section{Discussion}

In this study, we received the enterotoxin $\mathrm{P}$ gene sequence from the gene bank and two pair primers were designed and the molecular method PCR were set up. Then, 350 clinical isolate of $S$. aureus strains were assayed. The results indicate that, the total enterotoxin $P$ gene containing strains were 98 (28\%) which 79 (22.57\%) of them produced other Enterotoxins (A-E). The strains carriers of enterotoxin P gene alone were only 19 strains (5.43\%). In addition, ELISA screening tests were conducted with the strains and the results showed that the enterotoxin A was the most prevalent (78\% staphylococcal strains were enterotoxin A producer). Sergeev et al. reported that all SEA gene-specific primers can also be used for successful amplification of the SEIP gene (20). Our study revealed that the specific primers for SEE gene could be amplified the different clone of SElP gene in clinical isolates. However, SElP was recently described that elicited an emetic response in Suncus murinus (the house musk shrew), but the emetic activity of SElP in human is unknown (21).

The role of staphylococcal enterotoxins (SEs) in different organs of the human body is not exactly clear. However, Staphylococcal enterotoxins (SEs) as superantigens have become a global challenge and receive intensive consideration. There are some reports revealing these 
substances have been known contribute to colonization and a broad-spectrum of diseases $(22,23)$, other than gastrointestinal tract complication. As, literature review revealed that the Staphylococcal enterotoxin $B(S E B)$ is a potent mitogen that elicits life-threatening polyclonal T-cell proliferation and cytokine production at very low level (24). However, the frequencies of infectious disease caused by SEs producer have been reported differently. In addition, a group of staphylococcal virulence factors called the superantigen-like proteins (SSL) has been reported (25).

Some investigators showed that the level of antibody specific to the $S$. aureus enterotoxins in carriage in later stages of pregnancy has been raised. They concluded that over $89 \%$ of women and infants have some protective antibody to the toxins, and antitoxin IgG levels are higher in cord blood samples compared to antenatal samples and some infants lack protection and could be at risk of toxininduced disease (26). Normanno et al. demonstrated that Enterotoxins of S. aureus are able of inducing a cytopathic effect in cell lines (27). Najera-Sanchez et al. showed that the most frequently produced types being SEA and SED. They found that the Levels of correlation between the presence of genes that encode for the production of SEs (as determined by polymerase chain reaction) and the expression of these genes (as determined by the indirect ELISA) were $100 \%$ for SEA and SEE, 86\% for SEC, 89\% for SED, and $47 \%$ for SEB (27).

These facts have allowed us force to extensive analysis of the distribution of $S$. aureus genetics elements encoding enterotoxin-like superantigens (SEls) to prevention of future complication. NCBI-Blast results from this study suggest that, the specific primers amplification ent E gene were able to amplify the fragment which shows $100 \%$ homology with different clone of staphylococcal Enterotoxin-Like Toxin Type P and only 81\% similarity with reference gene. While, the specific primers for entP gene was amplified a fragment gene (700 bp) showed 100\% homology with reference gene (enterotoxin P gene, accession number BA000018.3).

In conclusion, the genetic similarity among the Enterotoxin A, E and P was found to be very high. Only 5.43\% of $S$. aureus strains were carriers of Enterotoxin P gene alone. In addition to Enterotoxin P gene, 22.57\% of strains were carrying other Enterotoxin gene. Therefore, this may suggest that the same mechanisms of pathogenic action in body site. However, Staphylococcal enterotoxin-like proteins as superantigens has necessitated intensive further investigation to determine frequencies of distribution.

\section{Acknowledgements}

The authors would like to thank the head of Baqiyatallah Research Institute, Dr. Mostafa Ghanei, for encouragement authors, Dr. Mohammad Rahbar (Reference Laboratory of Iran) for providing quality control bacterial strains, and Dr. Mahdy Kamali for technical assistants.

\section{Authors' Contribution:}

Ramezan Ali Ataee, Rahim mansuor Khanshan and Mohammad Hosein Ataee developed the original idea and the protocol, abstracted and analyzed data, wrote the manuscript. Ramezan Ali Ataee, Mojtaba Hedaiati ch and Mohammad Hosein Ataee contributed to the abstracted data, and prepared the manuscript.

\section{Financial Disclosure:}

None declared.

\section{Funding/Support:}

The authors have no conflict of interest.

\section{References}

1. Kerouanton A, Hennekinne JA, Letertre C, Petit L, Chesneau O, Brisabois A, et al. Characterization of Staphylococcus aureus strains associated with food poisoning outbreaks in France. Int J Food Microbiol. 2007;115(3):369-75.

2. Orwin PM, Fitzgerald JR, Leung DY, Gutierrez JA, Bohach GA Schlievert PM. Characterization of Staphylococcus aureus enterotoxin L. Infect Immun. 2003;71(5):2916-9.

3. Fooladi AA, Sattari M, Hassan ZM, Mahdavi M, Azizi T, Horii A. In vivo induction of necrosis in mice fibrosarcoma via intravenous injection of type B staphylococcal enterotoxin. Biotechnol Lett. 2008;30(12):2053-9.

4. Hong SW, Kim MR, Lee EY, Kim JH, Kim YS, Jeon SG, et al. Extracellular vesicles derived from Staphylococcus aureus induce atopic dermatitis-like skin inflammation. Allergy. 2011;66(3):351-9.

5. Brogan PA, Shah V, Clarke LA, Dillon MJ, Klein N. T cell activation profiles in Kawasaki syndrome. Clin Exp Immunol.2008;151(2):26774.

6. Van Zele T, Vaneechoutte M, Holtappels G, Gevaert P, van Cauwenberge P, Bachert C. Detection of enterotoxin DNA in Staphylococcus aureus strains obtained from the middle meatus in controls and nasal polyp patients. Am J Rhinol. 2008;22(3):223-7.

7. Hofer MF, Newell K, Duke RC, Schlievert PM, Freed JH, Leung DY. Differential effects of staphylococcal toxic shock syndrome toxin-1 on B cell apoptosis. Proc Natl Acad Sci U S A. 1996;93(11):542530 .

8. Schlievert PM, Case LC. Molecular analysis of staphylococcal superantigens. Methods Mol Biol. 2007;391:113-26.

9. Schlievert PM, Case LC, Strandberg KL, Abrams BB, Leung DY Superantigen profile of Staphylococcus aureus isolates from patients with steroid-resistant atopic dermatitis. Clin Infect Dis. 2008;46(10):1562-7.

10. Johnson WM, Tyler SD, Ewan EP, Ashton FE, Pollard DR, Rozee KR. Detection of genes for enterotoxins, exfoliative toxins, and toxic shock syndrome toxin 1 in Staphylococcus aureus by the polymerase chain reaction. JClin Microbiol. 1991;29(3):426-30.

11. Sharma NK, Rees CE, Dodd CE. Development of a single-reaction multiplex PCR toxin typing assay for Staphylococcus aureus strains. Appl Environ Microbiol. 2000;66(4):1347-53.

12. Chen TR, Chiou CS, Tsen HY. Use of novel PCR primers specific to the genes of staphylococcal enterotoxin $\mathrm{G}, \mathrm{H}$, I for the survey of Staphylococcus aureus strains isolated from food-poisoning cases and food samples in Taiwan. Int J Food Microbiol. 2004;92(2):189-97.

13. Chiang YC, Liao WW, Fan CM, Pai WY, Chiou CS, Tsen HY. PCR detection of Staphylococcal enterotoxins (SEs) N, O, P, Q, R, U, and survey of SE types in Staphylococcus aureus isolates from foodpoisoning cases in Taiwan. Int J Food Microbiol. 2008;121(1):66-73.

14. Gomez-Lucia E, Goyache J, Orden JA, Blanco JL, Ruiz-Santa-Quiteria JA, Dominguez L, et al. Production of enterotoxin A by sup- 
posedly nonenterotoxigenic Staphylococcus aureus strains. Appl Environ Microbiol.1989;55(6):1447-51.

15. Omoe K, Imanishi K, Hu DL, Kato H, Fugane Y, Abe Y, et al. Characterization of novel staphylococcal enterotoxin-like toxin type P Infect Immun. 2005;73(9):5540-6.

16. Omoe K, Nunomura W, Kato H, Li ZJ, Igarashi O, Araake M, et al High affinity of interaction between superantigen and $\mathrm{T}$ cell receptor Vbeta molecules induces a high level and prolonged expansion of superantigen-reactive CD4+ T cells. J Biol Chem. 2010;285(40):30427-35.

17. Ataee RA, Mehrabi-Tavana A, Izadi M, Hosseini SM, Ataee MH. Bacterial meningitis: a new risk factor.J Res Med Sci. 2011;16(2):207-10.

18. Nemati M, Hermans K, Vancraeynest D, De Vliegher S, Sampimon OC, Baele M, et al. Screening of bovine coagulase-negative staphylococci from milk for superantigen-encoding genes. Vet Rec. 2008;163(25):740-3.

19. Sambrook J, Russell DW. Molecular Cloning: A Laboratory Manual. 2001.

20. Sergeev N, Volokhov D, Chizhikov V, Rasooly A. Simultaneous analysis of multiple staphylococcal enterotoxin genes by an oligonucleotide microarray assay. J Clin Microbiol. 2004;42(5):213443.

21. Wang S, Li Y, Xiong H, Cao J. A broad-spectrum inhibitory peptide against staphylococcal enterotoxin superantigen SEA, SEB and SEC. Immunol Lett. 2008;121(2):167-72.

22. Cook E, Wang X, Robiou N, Fries BC. Measurement of staphylococcal enterotoxin $\mathrm{B}$ in serum and culture supernatant with a capture enzyme-linked immunosorbent assay. Clin Vaccine Immunol. 2007;14(9):1094-101.

23. Nowrouzian FL, Dauwalder O, Meugnier H, Bes M, Etienne J, Vandenesch F, et al. Adhesin and superantigen genes and the capacity of Staphylococcus aureus to colonize the infantile gut.J Infect Dis. 2011;204(5):714-21.

24. Fraser JD, Proft T. The bacterial superantigen and superantigenlike proteins. Immunol Rev. 2008;225:226-43.

25. Harrison LM, Morris JA, Lauder RM, Telford DR. The effect of Staphylococcus aureus carriage in late pregnancy on antibody levels to staphylococcal toxins in cord blood and breast milk FEMS Immunol Med Microbiol. 200 8;54(1):137-43.

26. Normanno G, Celano G, Dambrosio A, Lassandro L, Buonavoglia C. Enterotoxins of Staphylococcus aureus induce a cytopathic ef fect in cell lines. New Microbiol. 2001;24(4):341-6.

27. Najera-Sanchez G, Maldonado-Rodriguez R, Ruiz Olvera P, de la Garza LM. Development of two multiplex polymerase chain reactions for the detection of enterotoxigenic strains of Staphylococcus aureus isolated from foods. J Food Prot. 2003;66(6):1055-62.

Please cite this paper as: Ataee RA, Hedaiatich M, Mansuor Khanshan R, Ataee MH. Molecular Screening of Staphylococcal Enterotoxin Type P Encoding Gene from Clinical Isolates. Jundishapur J Microbiol. 2013.6(5):e6365. DOI:10.5812/jjm.6365 